This PDF is a selection from a published volume from the National Bureau of Economic Research

Volume Title: Law and Employment: Lessons from Latin American and the Caribbean

Volume Author/Editor: James J. Heckman and Carmen Pagés, editors

Volume Publisher: University of Chicago Press

Volume ISBN: 0-226-32282-3

Volume URL: http://www.nber.org/books/heck04-1

Conference Date: November 16-17, 2000

Publication Date: August 2004

Title: Labor Market Regulation and Employment in the Caribbean Author: Andrew Downes, Nlandu Mamingi, Rose-Marie Belle Antoine

URL: http://www.nber.org/chapters/c10077 


\title{
Labor Market Regulation and Employment in the Caribbean
}

\author{
Andrew S. Downes, Nlandu Mamingi, and \\ Rose-Marie Belle Antoine
}

\subsection{Introduction}

One of the major economic challenges facing the Caribbean is the generation of employment opportunities to reduce the high levels of unemployment experienced primarily among the young and female segments of the workforce. Although several reasons have been suggested for the high levels of unemployment in the region, little attempt has been made to rigorously assess the underlying causes of unemployment. An analysis of unemployment requires an examination of both the supply and demand sides of the labor market.

This research project focuses on the demand side of the labor market by examining the impact that labor market regulations have had on employment creation in the English-speaking Caribbean countries of Barbados, Jamaica, and Trinidad and Tobago. Although a recent Inter-American Development Bank (IADB) report on labor market reform in Latin America and the Caribbean indicates that the English-speaking Caribbean countries

Andrew S. Downes is professor and director of the Sir Arthur Lewis Institute of Social and Economic Studies, University of the West Indies. Nlandu Mamingi is senior lecturer in the Department of Economics, University of the West Indies. Rose-Marie Belle Antoine is a senior lecturer in law in the Faculty of Law, University of the West Indies.

We would like to thank Professors Daniel Hamermesh, Jim Heckman, and Giussepe Bertola and Carmen Pagés for their comments on various drafts of this paper. We are also grateful to the referees for constructive comments on the last draft of this paper. The participants at the various seminars organized by the office of the Chief Economist of the InterAmerican Development Bank provided useful suggestions and a stimulating environment. Research assistants Cyrlene Odle and Adrian Carter provided valuable statistical assistance at different stages of the project. A number of law students of the Cave Hill Campus, University of the West Indies, assisted with the identification of labor legislation. Doris Downes ably typed and edited the paper. 
have a lower level of labor market inflexibility than Latin American countries, the regulatory environment in both the labor and commodity markets has had some adverse impact on employment creation in the region (IADB 1996). Results from a study of the operations of the labor market in the Caribbean Group for Cooperation in Economic Development (CGCED) suggest that these regulatory measures do have some effect on the operation of businesses in the region (see Abt Associates 1998).

Labor market regulation generally refers to the range of economic, social, and judicial measures and mechanisms that affect labor market outcomes and behavior. Such regulation emerges from the legislative machinery of the government, case or common law, and the collective bargaining process between labor unions and employers. Labor market regulatory measures cover such areas as the following:

- The establishment and protection of workers' rights

- The protection of the vulnerable

- The establishment of minimum compensation for work

- The assurance of decent working conditions

- The provision of income security (see table 10.1)

Regulatory measures may be direct (i.e., via the legislative machinery or government intervention) or indirect (i.e., via the voluntaristic collectivebargaining process or custom and tradition). While such measures protect

Table 10.1 Labor Market Regulation Measures

\begin{tabular}{|c|c|}
\hline Type of Intervention & Guarantees and Policies \\
\hline $\begin{array}{l}\text { Establishment and protection } \\
\text { of workers' rights }\end{array}$ & $\begin{array}{l}\text { Right to associate and organize, right to bargain collectively, right to } \\
\text { engage in industrial action, right to contest dismissals, job protection } \\
\text { during strikes, conciliation and arbitration to resolve conflict }\end{array}$ \\
\hline Protection for the vulnerable & $\begin{array}{l}\text { Minimum working age to avoid child labor; equality of wages and } \\
\text { employment opportunities; antidiscrimination policies covering race, } \\
\text { sex, age, disability; special provision for women (such as maternity } \\
\text { leave with pay); restriction on temporary contracts with respect to } \\
\text { contingent workers; paternity leave; occupational licensing; immi- } \\
\text { gration laws }\end{array}$ \\
\hline $\begin{array}{l}\text { Establishment of minimum } \\
\text { compensation for work }\end{array}$ & $\begin{array}{l}\text { Minimum wages, minimum nonwage benefits, overtime pay, bonus } \\
\text { payments, night work }\end{array}$ \\
\hline $\begin{array}{l}\text { Assurance of decent working } \\
\text { conditions }\end{array}$ & $\begin{array}{l}\text { Minimum occupational health and safety conditions, maximum } \\
\text { hours of work with break periods, holiday with pay }\end{array}$ \\
\hline Provisions of income security & $\begin{array}{l}\text { Social security provisions (disability, layoff, old age, sickness), job } \\
\text { security and severance pay, wage and price controls, pension regula- } \\
\text { tions, gratuity, advance notice with pay, unemployment insurance, } \\
\text { temporary provisions }\end{array}$ \\
\hline
\end{tabular}

Source: Adapted from World Bank $(1995,71)$. 
workers from exploitation and poor working conditions, they represent additional costs to employers. The challenge for policymakers is to design a regulatory system that minimizes the additional labor (i.e., adjustment) costs to employers while protecting the socioeconomic welfare of workers in the labor market. By minimizing such labor costs, employers would be in a better position to hire more workers given other favourable economic conditions. It should be noted that labor market regulation represents only one variable that affects the employment of persons in the labor market.

The main objectives of this research project are these:

1. To document the range of labor market regulations existing in the three English-speaking members of the IADB

2. To identify the cost implications of such regulations

3. To empirically determine the impact that such measures have on employment determination using econometric methods

This report documents the findings of research undertaken to determine the impact of labor market regulation on employment in the Englishspeaking Caribbean countries. Given data availability, the empirical section only deals with Barbados, Jamaica, and Trinidad and Tobago. The structure of the presentation is as follows: In section 10.2, the institutional framework governing the operation of the labor market is outlined. The nonwage cost implications of this framework are examined in section 10.3. An attempt is made to develop indexes of labor market regulation based on the various provisions in labor regulation and, to a lesser extent, in collective bargaining agreements. The incorporation of nonwage labor costs into labor demand function is examined in section 10.4. The statistical data used in the estimation process are examined in section 10.5, while the empirical results are presented in section 10.6. The possible policy implications of the research are given in a closing section.

\subsection{Institutional Framework}

One aspect of the institutional framework governing the operation of the labor market is the judicial or legislative (direct) aspect of the labor market regulation. The main areas covered by this form of labor market regulation in the Caribbean include freedom of association and industrial action in the form of trade union activity; statutory regulation of dispute settlement (via conciliation or arbitration); the enforceability of collectivebargaining agreements; the recognition of unions; alternative contracts of employment; national insurance and social security; occupational health and safety; maternity and sick leave; overtime and holidays with pay; termination of employment; redundancy and severance; minimum wages; gender equality; equal remuneration; and regulations governing the employment of children. In addition to these legislative measures, labor unions and 
employers negotiate collective-bargaining agreements that contain measures covering hours of work; shift work; the payment of allowances such as uniform, entertainment, laundry, and hazard allowances; leave arrangements; manning levels; dismissal rules (LIFO); training of workers; and grievance procedures. The nature and extent of these regulations vary from country to country in the region (see table 10.2). Labor law in the Caribbean is characterized by a mixture of legislation, common law doctrines, custom and policy.

The institutional framework governing industrial relations in the region varies from a model of statutory intervention, as observed in Trinidad and Tobago, to the voluntaristic model followed in Barbados. The differences in the institutional framework within the region have emerged from the culture of trade unionism and the need to maintain labor and economic stability in order to propel economic development. For example, Jamaica and Trinidad and Tobago are known to have much more militant trade union movements than Barbados and Belize. In Guyana, Trinidad and Tobago, and the Bahamas, there are statutory provisions making all collective agreements legally enforceable, while in Barbados there is no such provision. There are no legal provisions for the recognition of a trade union in Barbados, Belize, and Guyana. The degree of unionization of labor varies from 13 percent of the labor force in Belize to 32 percent in Guyana (see Rama 1995). Although the degree of unionization appears to be low, the labor unions still have significant membership in strategic sectors of the economy (e.g., the public sector, ports, public utilities).

However, in all of the countries of the region, the original approach was based on the common law-that is, the voluntaristic model, which is still observed in certain countries. This is an important factor in attempting to explain the relative lack of movement in labor law regulatory indexes. The common law, unlike the civil law systems of Latin America, is based on case law and is characterized by ad hoc formulation of legal rules and regulations. In contrast, in the civil law systems, law is characterized by legal legislation and the code, which are deliberate forms of legal policy making. This has had ramifications for labor law regulation in common-law countries because the defining characteristic in common law is nonintervention by government. Labor regulation is therefore dependent on market forces and the strength of the bargaining parties. Legislation is usually relatively late in coming, and even where it occurs it is often distorted by case law.

Key concepts such as redundancy, the recognition of unions, the obligation to pay wages, and holidays with pay were left to the courts to determine. This explains why before the relatively late coming of legislation in the region, mainly in the late 1960s, the economic value of these key concepts stood at zero because the common law had made no provision for them.

In this study we focus on three main areas of labor market regulation in the Caribbean, namely, national insurance payments, severance payments, and minimum wages. 


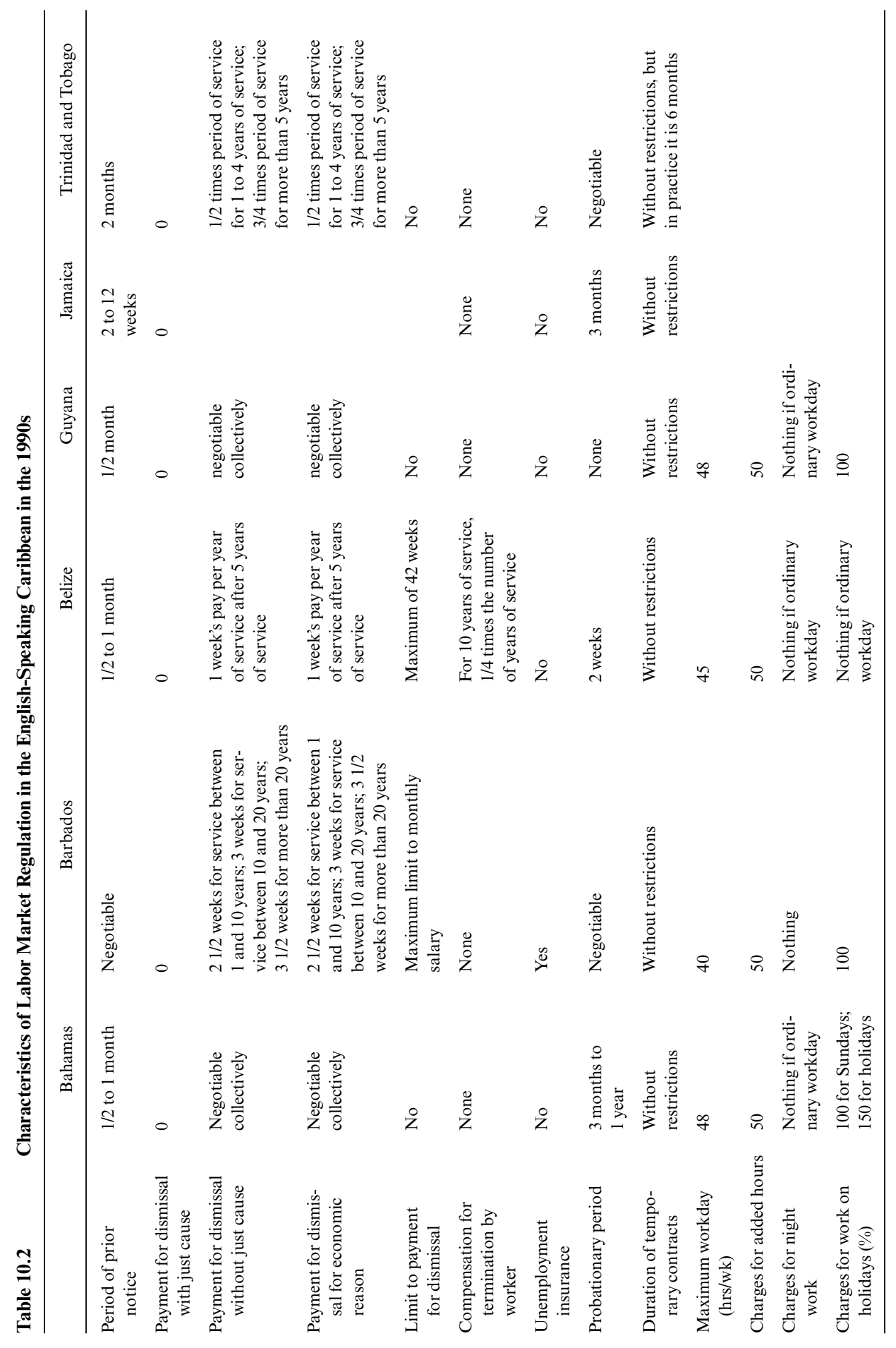


National insurance and social security benefits are provided in all countries. Benefits cover such areas as medical care, sickness, unemployment, old age/pension/retirement, employment injury, maternity, invalidity, and survival. Although there are differences in the range of benefits provided, all the countries satisfy the minimum standards set by the International Labour Organization. Both employers and employees contribute to the national insurance and social security schemes, which can be considered as payroll taxes. The contribution rates for employees and employers to social insurance schemes are given in table 10.3. The payment of such contributions by employers can represent a significant part of their labor costs, and several employers have been delinquent in their payments to the national insurance scheme. In Barbados, several employers find such contributions relatively high and become delinquent with respect to their payments into the national insurance fund.

The most contentious area of labor law in the region relates to the termination of workers and calculation of associated firing costs to employers (see Antoine [1998] for a full discussion). Employment is usually governed by a mixture of contract and law. Pure contract law principles, which do not usually consider the peculiar relationship of the worker to his or her employment, may also govern the labor law environment. For example, by common law, termination is generally regarded as an essentially contractual concept. This means that A contracts to work for B, and if he does not perform adequately for any reason, such as poor performance, strike, or even serious illness, he has breached the fundamental term of the contract and may be lawfully dismissed. "Summary dismissal" is termination without notice for such actions as misconduct and breaches of confidentiality. The common-law presumption of "dismissal at will" still operates in the region with regard to the termination of employment. By common law, a contract of employment can be terminated at will provided "reasonable notice" is given. If there is no notice, the terminated employee gets payment in lieu of notice (e.g., one week's wage or one month's salary). Wrongful dismissal

Table 10.3

Contribution Rates to Social Insurance Schemes (1991)

\begin{tabular}{lccc}
\hline & \multicolumn{3}{c}{ Contribution Rates (\%) } \\
\cline { 2 - 4 } Country & Employer & Employee & Self-Employed \\
\hline Bahamas & 5.4 & $1.7-3.4$ & $6.8-8.8$ \\
Barbados & $4.9-6.8$ & $4.65-6.55$ & 8 \\
Guyana & 7.2 & 4.8 & 10.5 \\
Jamaica & 2.5 & 2.5 & 5.0 \\
Trinidad and Tobago & 5.6 & 2.8 & n.a. \\
\hline
\end{tabular}

Source: La Foucade (1995, 32-33).

Note: n.a. $=$ not available. 
occurs where there is no evidence for termination without notice (i.e., no contractual breach). The issue of notice is therefore fundamental to the concept of the lawful termination of employment in common law.

Although industrial courts and tribunals place some degree of constraint on the freedom of employers to dismiss at will, Caribbean governments are considering the formal introduction of "unfair dismissal," which means that the employer must demonstrate that there is good reason for dismissing an employee. This clearly has implications for the future hiring and firing decisions of employers. Trinidad and Tobago, through its Industrial Court, specifies the concept of unfair industrial relations practice, while Jamaica has provision for "justifiable dismissal." In both cases, reasons for dismissal must be given. In Barbados, where an employee has been dismissed without notice, the concept of "just cause" has been employed to determine if the dismissal is wrongful (see Antoine 1992; Cumberbatch 1995a,b). Damages for such dismissal are paid via provisions in the severance payment legislation. It should be noted that workers taking strike action in Belize, Barbados, Guyana, and Jamaica can be dismissed. Good industrial relations practice, however, reduces the occurrence of such cases, since firms seek to maintain a reputation for being good employers in order to attract high-quality workers who can expect some degree of job security.

In terms of payment for involuntary termination of employment, labor law provides for severance pay (i.e., compensation for termination of employment for whatever reason) and redundancy pay (i.e., compensation for termination due to the existence of economic or technological difficulties; see table 10.4). The redundancy pay concept is more widely used in the region. Redundancy or severance pay is treated as payment for past service; hence, low-tenured workers are severed first on cost-minimizing grounds. Employers in some countries (e.g., Barbados) are responsible for paying severance to employees when they are terminated and then recovering part of the payment from a Severance Payment Fund. In Barbados, the Severance Payments Fund is administered by the National Insurance Board. Employers must make severance fund contributions on behalf of their employees based on their insurable earnings. Employers are required to pay employees their severance and then claim a rebate, which is determined by the minister responsible for the fund's administration. In cases where the employers are unable to make payments to employees, the fund makes the payments to the employees and then seeks to recover the amount from the employers. The severance payments system is not experience rated; hence, employers do not pay a reduced contribution to the fund if they have a long history of nonseverance. In Jamaica and Trinidad and Tobago, there is no fund, so the employer pays the employee the full cost of termination without receiving a refund.

The countries under study in this project have enacted minimum-wage legislation in the form of either a national minimum wage (e.g., Jamaica) 
Table 10.4

Severance Pay in Caribbean Countries in the 1990s

\begin{tabular}{|c|c|c|}
\hline Country & $\begin{array}{l}\text { Qualifying } \\
\text { Service }\end{array}$ & Rate of Benefit \\
\hline Antigua and Barbuda & 1 year & 12 days per year at latest basic wage \\
\hline Barbados & 2 years & 12.5 days per year for first 9 years \\
\hline Belize & 5 years & 5 days per year with 42 weeks maximum \\
\hline Dominica & 3 years & $\begin{array}{l}5 \text { days for first } 3 \text { years }+10 \text { days per year for } 3 \text { to } 5 \\
\text { years; } 45 \text { days for next } 5 \text { years }+10 \text { days per year } \\
\text { for } 6 \text { to } 10 \text { years; } 95 \text { days for over } 10 \text { years }+15 \text { days } \\
\text { per year for over } 10 \text { years; maximum is } 52 \text { weeks }\end{array}$ \\
\hline Jamaica & 2 years & $\begin{array}{l}10 \text { days per year for first } 5 \text { years; } 15 \text { days per year for } \\
\text { first } 2 \text { years }\end{array}$ \\
\hline St. Kitts and Nevis & 1 year & $\begin{array}{l}10 \text { days per year for first } 4 \text { years; } 15 \text { days per year for } \\
5 \text { to } 10 \text { years; } 20 \text { days per year for over } 10 \text { years; } \\
\text { maximum is } 52 \text { weeks } 10 \text { days per year }\end{array}$ \\
\hline St. Lucia & 2 years & $\begin{array}{l}5 \text { days per year for first } 2 \text { years; } 10 \text { days per year for } \\
3 \text { to } 7 \text { years; } 15 \text { days per year for over } 7 \text { years; weekly } \\
\text { wage limited to EC } \$ 100\end{array}$ \\
\hline St. Vincent and the Grenadines & 2 years & 10 days per year up to 52 weeks \\
\hline Trinidad and Tobago & 1 year & $\begin{array}{l}10 \text { days per year for first } 5 \text { years; } 15 \text { days for over } 5 \\
\text { years }\end{array}$ \\
\hline
\end{tabular}

Source: Baker (1997).

or specific minimum wages for selected occupations (e.g., Barbados). In Jamaica, a national minimum wage was introduced in 1975 as part of the government's poverty alleviation program and in recognition that several workers in the nonunionized sectors were low paid. The most recent increase in the national minimum wage took place in January 2002, when it was set at J\$1800 per forty-hour week. Barbados, Belize, Guyana, and Trinidad and Tobago (up to 1998) have minimum wages to cover selected workers (e.g., shop assistants, domestic workers, and agricultural workers). These rates are updated on an irregular basis. In June 1998, Trinidad and Tobago introduced the Minimum Wage Act, which specified a national minimum wage of TT\$7 (US\$1.10) per hour.

Antoine (1998) also discusses other aspects of labor law in the region, namely, sick leave with pay, holiday with pay, temporary employees, the protection of wages, truck acts and other benefits, the employment of child labor, gender equality, and equal remuneration. These regulatory measures form the general background against which firms have to operate in the labor market. Little change has taken place in these legislative measures over the years, so firms have adjusted to their existence.

In summary, the institutional framework governing the operation of the 
labor market in the Caribbean consists of a set of legislative measures, common-law provisions (case law), customs, and traditions. This range of regulations reflects the existence of two types of models of industrial relations and dispute regulation in the region, namely, statutory intervention and voluntarism. Trade unions are particularly active in the labor market and are recognized in the various labor laws. The state maintains an oversight on the operations of the labor market in the region in the form of legislative provisions and the operation of labor departments. While individual regulatory measures may affect companies (e.g., employers) differently, the overall framework within which companies can hire and fire workers provides the basis on which employment decision making is made. Changes in labor legislation have not been undertaken regularly.

The change in employment depends on the hiring and firing process. If we let $L_{0}$ and $L_{t}$ represent the initial and current levels of employment (i.e., number of persons employed), then we have the relationship

$$
L_{t}=L_{0}+H(\cdot)-F(\cdot)-R,
$$

where $H(\cdot)$ represents the hiring function and $F(\cdot)$ is the firing function. $R$ represents the number of voluntary resignations and retirements. Mandatory retirement laws will affect the $R$ variable. The discrete change in employment over the time period is given by

$$
\Delta L_{t}=L_{t}-L_{0}=H(\cdot)-F(\cdot)-R .
$$

The change in employment therefore depends on the factors that affect the hiring and firing processes. Regulatory measures can either impose additional costs of hiring and firing (e.g., severance, national insurance contributions, and other payroll taxes) or condition the processes (i.e., no discrimination in the hiring process, no child labor, LIFO, or inverse seniority in the firing process). Understanding the factors that affect the $H$ and $F$ functions becomes important in determining changes in employment over time.

\subsection{Nonwage Labor Cost Indexes}

Labor market regulations give rise to a set of labor costs that employers must take into consideration. Labor costs can be classified into (direct) wage costs and (indirect) nonwage costs. Direct wages and salaries relate to remuneration for work performed and include pay for normal time worked, premium pay for overtime and public holiday work, premium pay for shift work and night work, incentive or bonus pay, and cost-of-living allowances. Indirect or nonwage labor costs consist of payment for days not worked (paid holidays and compensation for holidays not taken), social welfare costs (contributions to social welfare and family allowances paid by the firm), statutory social welfare costs (e.g., contributions to national insur- 
ance and social security schemes), customary contractual or voluntary costs (e.g., supplementary retirement and provident schemes, supplementary redundancy insurance schemes), benefits in kind (e.g., housing, payment of utility bills), vocational training, and special taxes and subsidies (e.g., employment tax).

In addition to giving rise to these wage and nonwage labor costs, labor market regulations (LMRs) also condition the environment within which companies must operate in the labor market. For example, legislation governing gender equality and equal remuneration and the recognition of a trade union may not affect labor costs directly but may affect the decision to hire and fire workers. The existence of the gamut of legislative measures therefore gives rise to the nature and structure of adjustment costs and makes the labor input a quasi-fixed factor in the production process.

The wide range of regulatory measures makes it difficult to properly analyze their effects on employment and other labor market variables. In some cases, many of the regulations hardly change over a long period and therefore have no intertemporal analytical significance. In other cases, some regulatory measures are changed on a regular basis and therefore provide a "natural experiment" for empirical analysis. Differences in regulation across countries also provide a basis for empirical analysis. In order to manage the range of regulatory measures, analysts have attempted to develop indexes of LMR (see Downes [2002] for a full discussion). Two basic approaches have been employed by labor economists. First, important regulatory measures are identified and specific indexes are developed for each measure (e.g., severance pay, minimum wage [i.e., Kaitz index], national insurance contribution, or payroll taxes). Second, composite indexes are constructed using either the specific indexes or the natural units of the regulatory measures. These composite indexes tend to be unweighted and do not reflect the relative importance of the different measures in the employment decision. The technical solution to this problem is the use of principal components or factor analysis for both qualitative and quantitative variables.

Authors have referred to LMR by different names. For example, Rama (1995) refers to LMR as an index of "labour market rigidity," while Márquez and Pagés (1998) refer to them as an index of "employment protection." Loayza and Palacios (1997) have used a similar procedure to obtain an indicator of labor market reform.

In Rama's (1995) study of thirty-one Latin American and Caribbean countries, the range of his "index of labour market rigidity" was 0.182 (Belize) to 0.654 (Brazil). The indexes for the English-speaking Caribbean are given in table 10.5. Although missing values for some of the variables can affect the overall value of the index, the values of the index of labor market rigidity in the English-speaking Caribbean indicate that Barbados has the highest degree of labor rigidity in the subregion, while Belize has the lowest. 


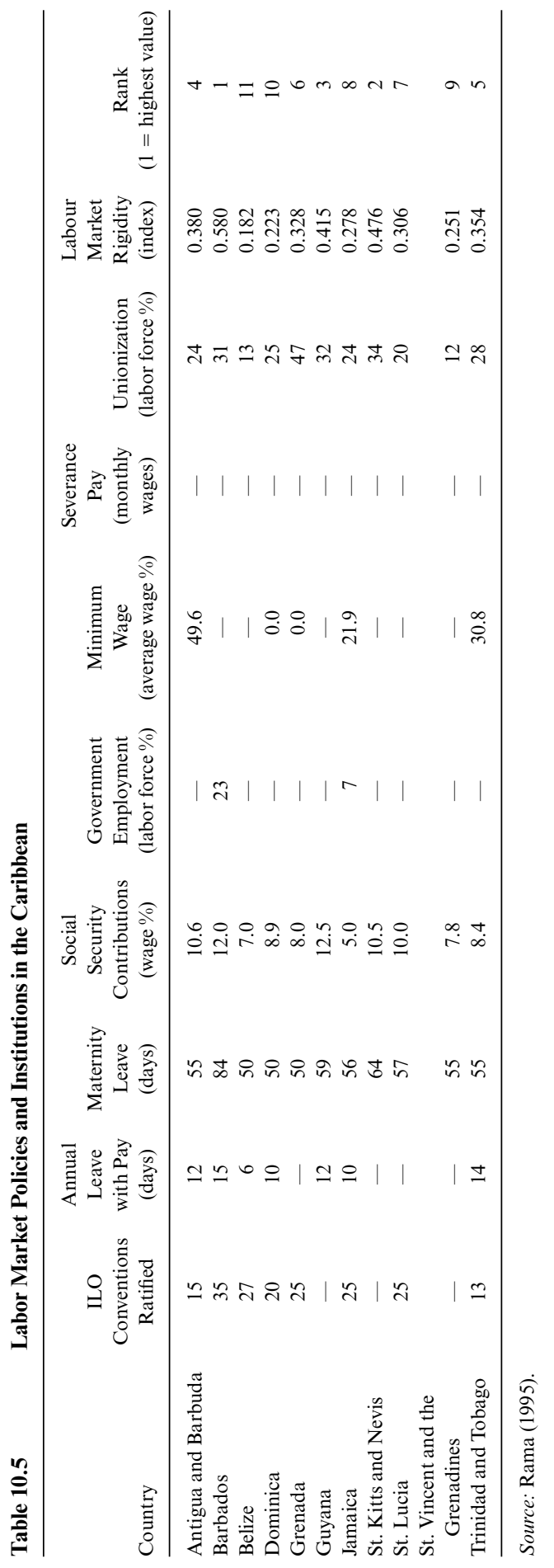


Márquez and Pagés's (1998) index of employment protection for the six countries in this study also show how levels of protection compared with Latin America. The range of their index goes from 1 (little protection, e.g., the United States) to 35.5 (high degree of protection, e.g., Bolivia and Nicaragua). Four of the six countries in this study record values less than 10 (see table 10.6). Loayza and Palacios's (1997) study of labor market liberalization in Latin America and the Caribbean also comes to the conclusion that low level of labor market distortion exist in the Caribbean compared with Latin America. They state that with a "common law tradition, the English-speaking countries of the Caribbean, especially the Bahamas, Belize and Guyana, are the least rigid in the region, particularly in regard to monetary compensation for dismissal, constraints on temporary contracts and the rate of payroll taxes" (17).

Although these composite indexes provide some indication of the degree of labor market rigidity, distortion, or protection afforded by various regulatory measures, they do not provide an indication of how specific measures affect employment. As indicated earlier, specific indexes can be constructed to determine the impact of LMR on other labor market variables.

In this study, specific indexes are used to examine the effects of labor regulations on employment in the Caribbean. In the case of minimum wage legislation, a Kaitz-type index (KE) is used for Jamaica, which has a national minimum wage. The index is given by

$$
\mathrm{KE}=\frac{\text { Minimum Wage Index }}{\text { Average Compensation Index }}=\frac{\mathrm{MW}}{\mathrm{AC}},
$$

where the coverage ratio is unity (see Brown, Gilroy, and Kohen 1982, 499). The traditional Kaitz index is the ratio of the nominal legal minimum wage to average hourly earnings weighted by coverage. For Jamaica, average compensation is used as a proxy for average earnings. In the case of Trinidad and Tobago, where the minimum wage legislation covers a selected number of workers, an "effective minimum wage index" is used. This index is given as the ratio of the minimum wage index for those covered by the legislation to the average earning index. Data on the degree of coverage are unavailable.

Simple unweighted indexes are used to measure the impact of national insurance contributions made by employers and employees in Barbados (because of the unavailability of data for weighting purposes). These contributions cover payments for severance pay, national insurance, and special levies. The overall contribution rates are converted to index number form using 1980 as a base. Simple unweighted indexes are also employed to capture the effect of the payment of wage-related contributions to the national insurance scheme in Jamaica. In the case of Trinidad and Tobago, a dummy variable is used to capture changes in the National Insurance Scheme (NIS) contributions, which started in 1971, and changed in 1980 and 1982. 


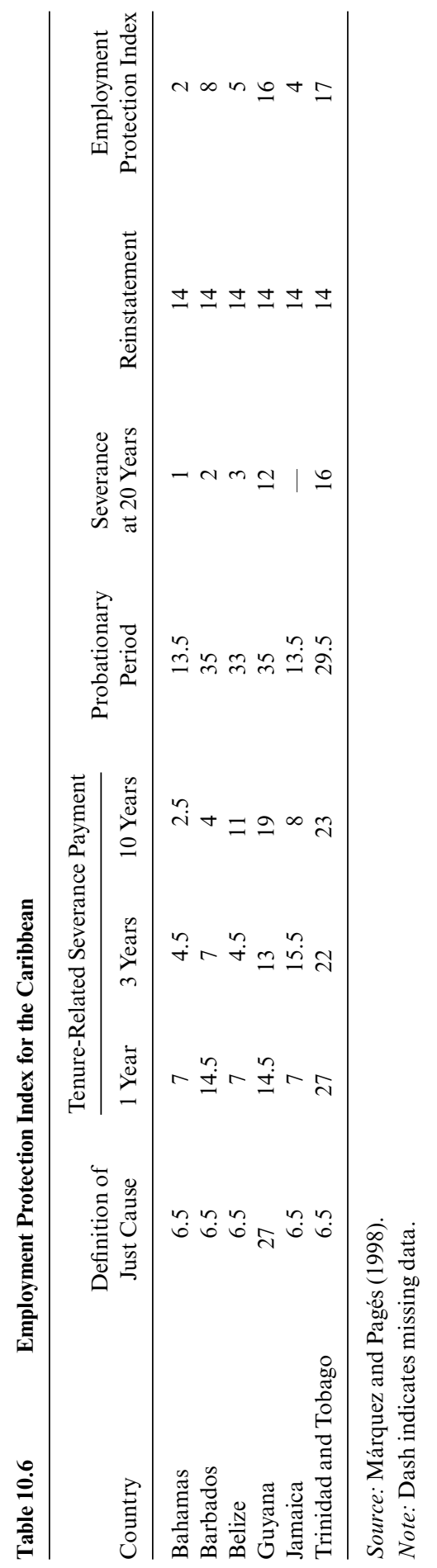


Severance payment legislation has not changed significantly over the study period. The severance payments scheme in Trinidad and Tobago started in 1985 and has not changed since that year. In the case of Barbados, the scheme started in 1978, and some amendments were made in 1991. The scheme in Jamaica began in 1974, and slight amendments were made in 1986 and 1988. With the exception of Barbados, where rates of contribution were changed, the amendments have been administrative.

In this study, therefore, the analysis of the effects of labor market regulations on employment will focus on minimum wage legislation, national insurance contributions, and severance payments.

\subsection{Dynamic Labor Demand Functions}

The employment of a person by a company involves various costs: (direct) wage costs and (indirect) nonwage costs. Direct wages and salaries relate to remuneration for work performed and include payment for normal time worked, overtime and holiday work, shift and night work, incentive pay, and family allowances. While the payment for some of these items is determined by legislation (e.g., holiday-with-pay legislation), the quantum of the payment is determined by the collective-bargaining process, in which unions are dominant.

The existence of nonwage labor costs, which make labor a quasi-fixed factor of production, has implications for the specification of labor demand (employment) functions and the employer's choice between the number of workers and the number of hours worked per employee. There are also implications for the incidence of layoffs by skill level since differences in such turnover costs by skill level can result in firms' being more reluctant to lay off skilled than unskilled workers in response to a decline in demand for goods and services (i.e., skilled labor is hoarded).

The impact of LMRs on employment, as reflected in wage and nonwage labor costs, has been approached from two directions:

- The estimation of dynamic labor (employment) adjustment models whereby the role of LMR is implicitly captured in an adjustment cost function (see, for example, Hamermesh 1993; Hamermesh and Pfann 1996)

- The estimation of labor (employment) demand functions explicitly using specific or composite indexes of LMR as explanatory variables (see, for example, Lazear 1990; Erickson and Mitchell 1995)

Dynamic labor demand functions can be motivated via the existence of adjustment costs or the role of expectations. These two factors suggest that there are several specifications of the dynamic labor demand function depending on the nature of adjustment costs and expectations. For example, labor adjustment costs may be symmetric or asymmetric with respect to 
the hiring or firing of employees, or linear or nonlinear (e.g., quadratic) with respect to the rate of increase in hiring or firing costs. Expectations can also take various forms - adaptive or rational.

In addition to adjustment costs and expectations, alternative labor demand models can be specified according to the assumptions made about the production technology used by the firm, the vintage of the capital stock, the structure of commodity and labor markets, and the institutional framework governing labor market behavior (e.g., the existence of trade unions and their bargaining power). Recent literature on the economics of the collective-bargaining and trade union behavior indicates several models that govern the negotiations process. The two main models are the labor demand and the efficient bargain. There are two variants of the labor demand model: first, the monopoly union model, in which the wage rate is set unilaterally by the union and the firm determines the appropriate level of labor demanded (i.e., employment); and second, the right-to-manage model, wherein the firm determines the demand for labor after the wage rate is determined by the bargaining process. In the efficiency bargain model, the union and the employer bargain over both the wage rate and the level of employment (see Sapsford and Tzannatos [1993] for an overview). The choice of a particular formulation has implications for the specification and estimation of wage and employment functions. Attempts have been made to develop dynamic wage and employment bargaining models in the context of adjustment costs (see Lockwood and Manning 1989; Modesto 1994). The specification of a dynamic labor demand function must therefore reflect the institutional features of the labor market and the behavior of firms in both the product and labor markets.

The standard formulation of the dynamic labor demand model emerges from the solution of an intertemporal constrained optimization problem. Assume that the representative firm has a level of employment at the beginning of a time period, $L_{0}$, and is faced with a cost of adjusting the level of employment over time while seeking to maximize profit or minimize costs. The cost of adjustment may be due to legislative, technological, or institutional factors. If the level of employment at some time period, $t$, is given as $L_{t}$, then the problem facing the firm is selecting the speed of adjustment to $L_{t}$ faced with an adjustment cost function and also the level of employment $L_{t}$.

The optimization problem can be solved by using the calculus of variation whereby the firm seeks to find the optimal path of employment over time (see Intriligator 1971). If we assume that adjustment costs are quadratic and symmetric - that is, firing costs are equal to hiring costs for all changes in employment - then we can generate one form of the dynamic labor demand function based on minimizing the intertemporal costs of production subject to a production function constraint (see Downes and Mamingi 1997) given as 


$$
L_{t}^{d}=L_{t}^{d}\left[\frac{W_{t}}{m_{t}}, q_{t}^{*}, D\left(L_{t}\right)\right],
$$

where the optimal demand for labor is a function of the price of labor relative to the rental price of capital $\left(W_{t} / m_{t}\right)$, planned or expected output $\left(q_{t}^{*}\right)$, and a distributed lag function of labor demand, $D\left(L_{t}\right)$. The specific form of equation (4) depends on the specification of the production function. As indicated earlier, alternative assumptions about firm behavior (e.g., profit maximization), the adjustment costs function (e.g., nonquadratic and nonsymmetric), institutional arrangements (e.g., right-to-manage bargaining model), and production technology can generate different dynamic labor demand functions.

One of the limitations of using equation (4) to determine the impact of LMRs on employment is that all sources of adjustment costs are subsumed in the $D\left(L_{t}\right)$ variable. One solution to this problem is to examine the nature and characteristics of LMR and specify regulatory measures related to the wage rate (e.g., payroll taxes) and nonwage regulatory measures (e.g., no child labor, right to join a trade union, no sex discrimination).

If indexes are specified for these regulatory adjusted measures, then a log-linear specification of the equation can be given as

$$
\begin{aligned}
\ln L_{t}^{d}= & \alpha_{0}+\alpha_{1} \ln \left(\frac{W_{t}}{m_{t}}\right)+\alpha_{2} \ln \operatorname{REG}\left(W_{t}\right)+\alpha_{3} \ln \operatorname{REG}\left(N W_{t}\right) \\
& +\alpha_{4} \ln q_{t}+\alpha_{5} \ln L_{t-1},
\end{aligned}
$$

where $\operatorname{REG}(W)$ and $\operatorname{REG}(N W)$ are regulatory indexes associated with the wage rate $(W)$ and nonwage $(N W)$ factors. Equation (5) indicates that the demand for labor depends on the basic wage rate relative to the price of capital services; wage-related regulatory measures (e.g., payroll taxes); nonwage regulatory measures, which are the main factors that make labor a quasi-fixed factor; planned output; and previous level labor demand (which is a proxy for factors other than labor market regulations that affect the adjustment process). In a truly dynamic context, we would expect some interaction between these explanatory variables.

As stated before, composite regulatory measures (indexes) are not particularly useful for specific policy analysis (e.g., whether government should reduce the minimum wage or cut severance pay to boost employment). In order to handle this issue, we need to examine the regulatory environment of a country to determine the main regulations that are likely to affect employment over time (see Zank 1996). In time series analysis, significant variation in regulatory measures can have an impact on employment determination. Across countries, significant variation can also have an impact on employment generation across these countries and explain differences in relative employment growth. Lazear (1990) approached the study 
of the impact of labor market regulation on employment by specifying the important measures that determine employment across a set of developed countries. An expanded version of his model can be given as

$$
L_{t}^{d}=L^{d}\left(\frac{W_{t}}{m_{t}}, q_{t}^{*}, r_{1}, r_{2} \ldots \ldots r_{k}\right),
$$

where $r_{i}(i=1, \ldots k)$ are alternate regulatory measures (e.g., severance payment, NIS payments). To the extent that there are still residual adjustment costs, a lagged function of $L_{t}$, can be incorporated into equation (6), that is,

$$
L_{t}^{d}=L^{d}\left[\frac{W_{t}}{m_{t}}, q_{t}^{*}, r_{1}, r_{2} \ldots r_{k}, D^{*}(L)\right] .
$$

$D^{*}(L)$ reflects residual adjustment costs.

The latter approach is more useful for policy analysis than the earlier specifications of the dynamic labor demand functions in that specific labor regulations can be highlighted. While some of the labor market regulatory variables can affect the basic wage rate (e.g., payroll taxes), the focus in this study is on the effects of the regulatory measures on labor demand. The possible endogeneity of the wage rate in the labor demand equation can be handled by an appropriate choice of instrumental variables.

\subsection{Statistical Data}

One of the major problems associated with labor market analysis in the Caribbean is the unavailability of data on many labor market variables. The authors of a recent study of workers and labor markets in the Caribbean lamented the unavailability of data with which to undertake a detailed analysis of the labor market (Abt Associates 1998). Some countries in the region have undertaken periodic labor force surveys to assess the performance of the labor market in terms of employment, unemployment, and labor force participation. Many of these countries rely, however, on population census data, which are collected on a decennial basis, in order to get a comprehensive picture of important labor market features.

Ideally, a specially designed survey would provide data to undertake a proper analysis of the impact of labor market regulation on employment at the different levels of aggregation.

The absence of the ideal situation means that we must use the available information from different sources. Such a situation makes the results of the exercise somewhat tentative since the databases may not be congruent. A typical situation in the Caribbean relates to the data available on wages and employment. Wage rate data are usually collected from the administrative records of the Labour Department and based on collective-bargaining agreements, while employment data are collected from labor force (continuous household) surveys. 
In terms of the database used in this study, only annual data are available for real gross domestic product (GDP) for all the countries. Data at the aggregate level are used in this study, although annual sectoral-level data for real GDP (constant price GDP) are available. The data series for real GDP are as follows: Barbados, 1970-2001; Trinidad and Tobago, 1970-1999; and Jamaica, 1975-2001.

Wage rate and average earnings data are available for only three countries on a continuous basis: Barbados, Jamaica, and Trinidad and Tobago. In the case of Barbados, the Central Bank has constructed a wage rate index using data from collective-bargaining agreements lodged in the Labour Department. This annual Wages Index is based on selected areas of economic activity and is available for the period 1970-2001.

In the case of Jamaica, the Statistical Institute of Jamaica conducts a quarterly Employment and Earnings Survey of large establishments (i.e., employing ten or more persons). Data are available on both a quarterly and annual basis for the average earnings of workers in large establishments for the periods 1976-1979 and 1986-2001. Because of this large gap in the establishment survey data, researchers have had to use the ratio of employees' compensation in the national income accounts to total employees as a proxy for average annual compensation in Jamaica.

The Central Statistical Office in Trinidad and Tobago publishes an index of average weekly earnings. This index was started in 1971 and rebased in 1977 with a wider coverage of employees in sugar, manufacturing, oil refining, and electricity. Data are collected from surveys conducted biannually.

Employment data are collected on a quarterly basis from labor force surveys in the Bahamas, Barbados, Belize, Jamaica, and Trinidad and Tobago. No ongoing survey exists in Guyana. Annual data on employment (and unemployment) in the Bahamas are available for 1973, 1975, 1977, 1979, 1986, 1988-1989, and 1991-1999. No quarterly estimates exist for the Bahamas. Barbados has conducted a quarterly Continuous Household Sample Survey to collect information on employment and other labor force data since 1975. In the case of Belize, a one-off labor force survey was conducted in 1983-1984, but since 1993 labor force data have been collected on an annual basis. Employment (and unemployment) data are available on a biannual basis (April and October) only for 1993 and 1994. Labor force surveys have been undertaken in Jamaica on a continuous basis since 1968. Between 1968 and 1987, six-monthly labor force surveys were conducted (April and October). Since 1988, quarterly data on the labor force have been collected. Labor force surveys began in 1963 in Trinidad and Tobago on a biannual basis (January-June and July-December), but there were no surveys in 1972 and 1976.

An assessment of basic data series for the six Caribbean countries covered in this study indicates that continuous annual data are available for 
Barbados (1970-2001), Jamaica (1975-2001), and Trinidad and Tobago (1970-1999).

The absence of wage/earnings data and a continuous employment series for the Bahamas, Belize, and Guyana means that they are excluded from the empirical aspect of this study. Given the low level of distortion caused by LMR in these countries, their exclusion would not affect the results of the study (see Loayza and Palacios 1997).

In terms of LMRs, we have sought to identify the main regulatory measures that are likely to affect employment in the three countries (Barbados, Jamaica, and Trinidad and Tobago). In several instances, there has been little change in LMRs in these countries. Indeed, a recent survey of companies in Barbados, Belize, Jamaica, and Trinidad and Tobago indicated that LMR was not an important labor market issue affecting their operations. There was, however, some concern expressed in Barbados and Trinidad and Tobago about the high level of employer contributions to the social security fund (see Abt Associates 1998, 26). The Severance Pay Act was also a concern to Barbadian employers. In this study, we have therefore focused on the impact of minimum wage legislation in Jamaica and Trinidad and Tobago and social security payments and severance payments in the three countries. Data are available on the national minimum wage introduced in Jamaica in 1975, while a minimum wage index covering selected occupations is available for Trinidad and Tobago. Barbados's minimum wage legislation only covers three categories of workers (shop assistants, domestics, and agricultural workers) who generally tend to receive more than the minimum wage.

Payroll taxes in the form of national insurance contributions are available for Barbados since 1967. The contribution rates for regular employees and employers are available along with the range of taxes paid. The employer is responsible for the partial payment of national insurance, noncontributory old age pension, employment injury, severance pay, and unemployment insurance. Special levies introduced since 1981 are shared by both employers and employees. The limits of insurance earnings have been adjusted periodically to ensure that the National Insurance Fund maintains an equality between income and expenditure. Changes were made in 1974, 1978, 1982, 1984, 1987, 1991, and 1994. Unweighted indexes of the rates for the different contributors (employers and employees) are used in this study. For Jamaica, data are available for the maximum wage-related contributions to the national insurance scheme for the period 1966-2001. In the case of Trinidad and Tobago, the contribution rates have not changed since the introduction of the national insurance scheme in 1971. The maximum insurable earnings were, however, increased in 1980, 1983, and 1999. Severance payment legislation was introduced in Jamaica in 1974 and in Trinidad and Tobago in 1985. No changes have been made with respect to the payment of employees since these periods. A severance payment scheme 
was introduced in Barbados in 1973. The contribution rate payable by employees into the severance payment fund was raised from 0.25 percent to 1 percent of insurable earnings in April 1991. The maximum on insurable earnings was also raised from $\$ 2,600$ to $\$ 3,100$ in October 1991.

In summary, the impact of minimum wage on employment is assessed for Jamaica and Trinidad and Tobago and on payroll taxes (national insurance contributions) and severance payments for all three countries using annual data. Little change has taken place in other LMRs over the study period (1970-2001) in these countries.

\subsection{Empirical Results}

In this section an empirical examination of the impact of selected LMRs on employment is undertaken using variants of equations (6) or (7). While annual data are used for the three countries (Barbados, Jamaica, and Trinidad and Tobago), the period of investigation varies from country to country according to the availability of data: Barbados, 1970-2001); Trinidad and Tobago, 1970-1999; and Jamaica, 1975-2001. The variables used in the exercise also vary from country to country according to the data availability. They are as follows: total number of persons employed $(L)$; average earnings index (Trinidad and Tobago); average compensation index (Jamaica) and average wage index (Barbados; $W$ ); GDP at factor cost at 1990 prices (GDP); real wage rate or earnings/compensation (RW), defined as $W$ divided by the retail or consumer price index $(P)$; minimum wage index (MW); the contribution of employers to the national insurance scheme (NISCOR); severance payment schemes (SEV); effective minimum wage (EMV), given as the minimum wage index divided by an average earnings index (Trinidad and Tobago); and the Kaitz index, defined as the ratio of the minimum wage index to an average compensation index (Jamaica; see the appendix for a discussion of the labor regulation variables).

Table 10.7 gives summary statistics of the data. At least three important features emerge from the reading of coefficients of variation. First, data variability is the rule rather than the exception. The highest variability is recorded by the average compensation index in Jamaica. The smallest variability is registered by the real wage in Barbados. Second, across countries, employment variabilities are statistically the same, and so are GDP variabilities. Third, overall, Jamaica data are more volatile than those of the two other countries.

As the study deals with the relationship between employment and a set of explanatory variables (including regulatory variables), at the very least an examination of correlations between the two sets of variables is warranted. Table 10.8 contains pairwise correlations between variables. The major observation is that correlations between employment and other variables are very high and positive, with the exception of real wage and 
Summary Statistics of Data

\begin{tabular}{|c|c|c|c|c|c|c|}
\hline & \multicolumn{2}{|c|}{ Barbados } & \multicolumn{2}{|c|}{ Jamaica } & \multicolumn{2}{|c|}{ Trinidad-Tobago } \\
\hline & Mean & C.V. $\%$ & Mean & C.V. $\%$ & Mean & C.V. $\%$ \\
\hline$L$ & 101.42 & 13.54 & 832.64 & 12.61 & 388.65 & 11.54 \\
\hline$P$ & 142.26 & 49.44 & 396.02 & 122.02 & 157.50 & 72.52 \\
\hline$W$ & 136.47 & 47.94 & 705.95 & 134.79 & 299.04 & 64.82 \\
\hline RW & 0.98 & 9.18 & 1.75 & 40.00 & 1.94 & 20.62 \\
\hline MW & & & 572.29 & 123.11 & 329.10 & 57.96 \\
\hline EMV (KAITZ) & & & 0.93 & 18.28 & 1.17 & 15.38 \\
\hline GDP & 790.39 & 13.45 & $2,171.75$ & 11.49 & $17,297.00$ & 14.42 \\
\hline NISCOR & 196.46 & 39.91 & 136.18 & 46.72 & 2.23 & 46.64 \\
\hline SEV & 1.09 & 71.56 & 2.11 & 45.97 & 0.50 & 102.00 \\
\hline Period & 1970-2001 & 1970-2001 & 1975-2001 & $1975-2001$ & 1970-1999 & 1970-1999 \\
\hline
\end{tabular}

Notes: Mean is data average; C.V. stands for coefficient of variation; $L$ represents total employment (in 000); $P$ stands for consumer (retail) price index; RW stands for real wage (ratio of nominal wage/earning/compensation index $[W]$ to consumer [retail] price index); GDP stands for gross domestic product at factor cost at some year prices; NISCOR is total employer contribution to national insurance; it is an unweighted simple index of the maximum wage-related payment for Jamaica, an unweighted index of rates (for employers and employees) for Barbados, and a count data variable (with a value of zero in 1970, a value of 1 in 1971-1979, a value of 2 in 1980-1982, a value of 3 in 1983-1998, and a value of 4 in 1999) for Trinidad and Tobago; EMV (effective minimum wage) is the minimum wage index divided by average earnings index for Trinidad and Tobago, and KAITZ index is defined as EMV for Jamaica; SEV represents severance payments; it is a count data variable capturing the change in regimes; for Barbados, it takes on a value of zero prior to 1978, 1 in 1978-1990, and 2 in 1991-2001; for Jamaica, it takes on a value of 1 in 1974-1985, 2 in 1986-1987, and 3 in 1988-2001; for Trinidad and Tobago, it is a dummy variable with a value of zero prior to 1985 and 1 in 1985-1999.

effective minimum wage. Of particular significance is the positive relationships between employment and regulatory variables. Moreover, explanatory variables are in general highly and positively correlated. These results must, however, be interpreted with caution because (1) simple correlation does not imply causality, (2) correlation may be spurious, and (3) simple correlation does not necessary capture multivariate relationships (i.e., multicollinearity problem).

It is worth pointing out two major problems encountered in this study. First, the exercise is hampered by the relative shortness of time series, which, in general, can result in the low power of test statistics as well as the invalidation of asymptotic tests. Second, as outlined earlier, the data used do not always capture adequately the concepts used in the theoretical analysis.

The estimation procedure proceeds as follows:

1. Investigate the temporal properties of the series using the augmented Dickey-Fuller (ADF) unit root test (and other unit root tests when appropriate).

2. Check for the existence of meaningful long-run economic relationships via the Johansen tests for cointegration. 
Table 10.8

Correlation Coefficient Matrices

\begin{tabular}{|c|c|c|c|c|c|c|c|}
\hline & $L$ & $P$ & $W$ & RW & GDP & NISCOR & SEV \\
\hline \multicolumn{8}{|c|}{ Barbados } \\
\hline$L$ & 1.00 & & & & & & \\
\hline$P$ & 0.90 & 1.00 & & & & & \\
\hline$W$ & 0.92 & 0.99 & 1.00 & & & & \\
\hline RW & -0.36 & -0.51 & -0.44 & 1.00 & & & \\
\hline GDP & 0.95 & 0.92 & 0.95 & -0.33 & 1.00 & & \\
\hline NISCOR & 0.72 & 0.91 & 0.91 & -0.38 & 0.78 & 1.00 & \\
\hline \multirow[t]{3}{*}{ SEV } & 0.82 & 0.94 & 0.92 & -0.51 & 0.84 & 0.83 & 1.00 \\
\hline & $L$ & MW & $W$ & KAITZ & GDP & NISCOR & SEV \\
\hline & \multicolumn{6}{|c|}{ Jamaica } & \\
\hline$L$ & 1.00 & & & & & & \\
\hline MW & 0.78 & 1.00 & & & & & \\
\hline$W$ & 0.72 & 0.99 & 1.00 & & & & \\
\hline KAITZ & 0.38 & 0.01 & -0.11 & 1.00 & & & \\
\hline GDP & 0.80 & 0.83 & 0.76 & 0.23 & 1.00 & & \\
\hline NISCOR & 0.90 & 0.80 & 0.72 & 0.44 & 0.82 & 1.00 & \\
\hline \multirow[t]{3}{*}{ SEV } & 0.94 & 0.69 & 0.62 & 0.43 & 0.85 & 0.81 & 1.00 \\
\hline & $L$ & MW & $W$ & EMV & GDP & NISCOR & SEV \\
\hline & \multicolumn{6}{|c|}{ Trinidad and Tobago } & \\
\hline$L$ & 1.00 & & & & & & \\
\hline MW & 0.81 & 1.00 & & & & & \\
\hline$W$ & 0.86 & 0.97 & 1.00 & & & & \\
\hline EMV & -0.56 & -0.45 & -0.57 & 1.00 & & & \\
\hline GDP & 0.68 & 0.39 & 0.37 & -0.23 & 1.00 & & \\
\hline NISCOR & 0.75 & 0.96 & 0.93 & -0.51 & 0.40 & 1.00 & \\
\hline SEV & 0.57 & 0.87 & 0.87 & -0.46 & 0.002 & 0.81 & 1.00 \\
\hline
\end{tabular}

Note: Variables are as defined in table 10.7.

3. Estimate, if cointegration holds, a long-run relationship between employment and a set of variables using the Phillips-Loretan nonlinear error correction model.

4. Use diagnostic criteria to evaluate the estimated model.

All results are derived from the Eviews computer program. The stationarity/nonstationarity of the series is determined with the ADF $t$-test. The following equation is used to derive the ADF $t$-test:

$$
\Delta y_{t}=c+\rho y_{t-1}+\sum_{i=1}^{m} \lambda_{i} \Delta y_{t-i}+e_{t},
$$

where $y_{t}$ is the variable of interest (any variable explained in the note to table 10.9), $\Delta$ stands for the first difference, $c$ is a constant term, $\rho$ and $\lambda_{i}$ are parameters, and $e_{t}$ is a white noise series. The optimal lag length $m$ is ob- 


\begin{tabular}{cccccccc}
\hline & & & & & & EMV or & \\
& & $L$ & WR & GDP & NISCOR & KAITZ & SEV \\
\hline Barbados & Level & 0.746 & $-1.592^{\mathrm{a}}$ & -1.590 & -1.267 & & -1.072 \\
1970-2001 & & $(5,0.991)$ & $(6,0.427)$ & $(1,0.473)$ & $(0,0.632)$ & & $(0,0.714)$ \\
& 1st & -2.835 & -3.184 & -3.170 & -4.028 & & -5.385 \\
& diff. & $(0,0.006)$ & $(5,0.003)$ & $(0,0.032)$ & $(0,0.000)$ & & $(0,0.000)$ \\
Jamaica & Level & -1.318 & -9.991 & -0.715 & -1.313 & -1.232 & -0.801 \\
1975-2001 & & $(0,0.606)$ & $(0,0.000)$ & $(1,0.827)$ & $(0,0.609)$ & $(3,0.642)$ & $(2,0.803)$ \\
& 1st & -4.171 & -13.318 & -3.331 & -3.743 & -6.761 & -3.162 \\
& diff. & $(0,0.000)$ & $(0,0.000)$ & $(0,0.002)$ & $(0,0.000)$ & $(0,0.000)$ & $(1,0.003)$ \\
Trinidad and & Level & -0.116 & -4.031 & -2.458 & -24.872 & -4.278 & -0.965 \\
Tobago & & $(0,0.939)$ & $(8,0.059)$ & $(2,0.136)$ & $(8,0.000)$ & $(0,0.002)$ & $(0,0.752)$ \\
1970-1999 & 1st & -2.964 & -2.319 & -1.417 & -7.845 & -10.849 & -5.196 \\
& diff. & $(0,0.004)$ & $(3,0.022)$ & $(1,0.142)$ & $(8,0.000)$ & $(0,0.000)$ & $(0,0.000)$ \\
\hline
\end{tabular}

Notes: $L$ represents the logarithm of total employment; WR stands for the logarithm of real wage (ratio of nominal wage/earning/compensation index to consumer (retail) price index); GDP stands for the logarithm of gross domestic product at factor cost at 1990 prices; NISCOR is total employer contribution to national insurance; it is the logarithm of an unweighted simple index of the maximum wage-related payment for Jamaica, the logarithm of an unweighted index of rates (for employers and employees) for Barbados, and a count data variable (with a value of zero in 1970, a value of 1 in 1971-1979, a value of 2 in 1980-1982, a value of 3 in 1983-1996, and a value of 4 in 1999 for Trinidad and Tobago; EMV (effective minimum wage) is the logarithm of minimum wage index divided by average earnings index for Trinidad and Tobago and KAITZ index is defined as EMV for Jamaica; SEV represents severance payments and is a count data variable capturing the change in regimes; for Barbados, it takes on a value of zero prior to 1978, 1 in 1978-1990, and 2 in 1991-2001; for Jamaica, it takes on a value of 1 in 1974-1985, 2 in 1986-1987, and 3 in 1988-2001; for Trinidad and Tobago, it is a dummy variable with a value of zero prior to 1985 and 1 in 1985-1999. For figures, the first entries are the ADF test values. The first figures in parentheses are the optimal lags from SIC, and the second figures are the one-sided $p$-values. Regressions in first differences have no constant term. Lag search: maximum values: 9, 8, 8, for Barbados, Jamaica, and Trinidad and Tobago, respectively.

a The lag is not optimal. With the optimal lag (3), the series is stationary (ADF: $-4.567, p$-value: 0.001 ). Nevertheless, the ADF test is invalid given the presence of structural breaks (in 1975 and in 1990). The PP test seems to reveal nonstationarity.

tained by Schwartz Information Criterion (SIC) over a maximum number of lags. The null hypothesis of $\rho=0$ (unit root) against the alternative hypothesis $\rho<0$ (stationarity) is tested using the $t_{\hat{\rho}}$ statistic, that is, the ADF $t$-statistic that follows a Dickey-Fuller (DF) distribution. The one-sided $p$-values associated with the $t$-statistic values are compared with the level of significance (10 percent, 5 percent, 1 percent) to decide on stationarity or nonstationarity of variables. When $\rho=0$, nonstationarity (unit root) is accepted with a drift $c$; that is, $y_{t}$ is nonstationary with a trend for $c \neq 0$; otherwise it is stationary around a constant mean but has no trend. The ADF $t$-values and their associated $p$-values for variables in levels $\left(y_{t}\right)$ as well as for variables in first differences $\left(\Delta y_{t}\right)$ are reported in table 10.9. Since the ADF $t$-test has low power in some situations (i.e., in the presence of structural break), the Phillips-Perron $Z_{t}$ and the Kwiatkowski-Phillips- 
Schmidt-Shin (KPSS) tests are also used when the ADF test results look unsatisfactory or suspicious. Note that the Phillips-Perron $Z_{t}-$ a more powerful test than the ADF test, which also follows a DF distributionuses a nonparametric correction to approximate autocorrelation in the error term of the DF regression (the ADF regression without lagged lefthand-side variables), unlike the ADF test. The KPSS test has stationarity as the null hypothesis and nonstationarity as the alternative hypothesis.

For Barbados, the results presented in table 10.9 indicate that all variables are nonstationary, that is, integrated of order one. Indeed, the $p$ values of the ADF tests for level variables are greater than the common levels of significance, while those for first-differenced variables are smaller than the levels of significance. For Jamaica, all variables are integrated of order one with the exception of real wage. For Trinidad and Tobago, while the cases of labor and severance are clear cut in the sense that they are integrated of order one, the cases of other variables need further investigation. Using the Phillips-Perron test, GDP (with a structural break in 1982) was found I(1) instead of I(2) as the ADF test indicates. Contribution to national insurance was found I(1) by Phillips-Perron and KPSS tests, and effective minimum wage was also found I(1) by KPSS test.

Since the variables are nonstationary, regression equations involving these variables are only valid if they produce stationary linear combination(s) - that is, if they are cointegrated. Several tests for cointegration are available. The Johansen trace and maximum eigenvalue tests are used here (see Maddala and Kim 1998, chap. 6). The trace test deals with the hypothesis that there are at most $r<n$ (number of variables) cointegrated relationships (vectors). The maximum eigenvalue test deals with the null hypothesis of $r+1$ cointegrating vectors versus $r$ cointegrating vectors. Although these tests are large sample tests, they are preferred over the Engle-Granger cointegration test since they can reveal the presence of more than one cointegrating relationship when we are dealing with more than two variables.

Given a cointegrating relationship between the variables of interest, we need to use robust methods to obtain unbiased and efficient estimates at least asymptotically. In this study, we adopt the Phillips-Loretan nonlinear error correction model (see Phillips and Loretan 1991). The basic idea behind this procedure is to obtain the long-run (static) estimates of the parameters of an equation by incorporating one or several lagged error (equilibrium) correction mechanisms and current first-differenced explanatory variables as well as their lags and leads. The following equation can be specified as follows:

(9) $l_{t}=c+X_{t} \boldsymbol{\beta}+\Gamma(B)\left(l_{t}-c-X_{t} \boldsymbol{\beta}\right)+\sum_{i=0}^{\infty} \boldsymbol{\alpha}_{i} \Delta X_{t-i}+\sum_{i=1}^{\infty} \boldsymbol{\delta}_{i} \Delta X_{t+i}+u_{t}$, 
where $l_{t}$ stands for the logarithm of the number of persons employed, $X_{t}$ is a matrix of explanatory variables (i.e., real wage, real gross domestic product, severance, minimum wage, and contribution to national insurance), $\Delta X_{t}=$ $X_{t}-X_{t-1}, u_{t}$ is a well-behaved error term, $\boldsymbol{\beta}=\left(\beta_{1}, \beta_{2}, \ldots\right)$ is a vector of parameters associated with explanatory variables, $\boldsymbol{\alpha}$ and $\boldsymbol{\delta}$ are also vectors of parameters, and $\Gamma(B)=\sum_{j=1}^{\infty} \gamma_{1 j} B^{j}$ with $B$ as the backward shift operator.

The nonlinear error correction model in equation (9) achieves full efficiency "in the limit by working to estimate (and eliminate) the effects of long-run feedback between the errors on the long-run equilibrium relationship and the errors that drive the regressors" (Phillips and Loretan $1991,426)$. In this connection, the leads of $\Delta X_{t}$ have an important role to play as their inclusion allows us to obtain errors that form a martingale difference sequence with respect to the errors that drive the long-run equilibrium and the errors that drive the explanatory variables. This is useful for estimator efficiency, unbiasedness, and inference (see Phillips and Lore$\tan [1992,426]$ for advantages of this method over other cointegration techniques). Maddala and Kim (1998) also corroborate Phillips and Loretan's views on the usefulness of the presence of lags and leads in the estimation of a cointegration equation, precisely when there is a unique cointegrating vector. As can be inferred, this method is an appropriate method for dealing with endogeneity of right-hand-side variables.

In reality equation (9) cannot directly be used as it stands; there is a need for truncation to make it operational. Given the small sample size, one lag and one lead of $\Delta X_{t}$ and $\Gamma(B)=\gamma_{11} B$ are used. Thus, equation (9) now reads

$$
l_{t}=c+X_{t} \boldsymbol{\beta}+\gamma_{11}\left(l_{t-1}-c-X_{t-1} \boldsymbol{\beta}\right)+\sum_{i=0}^{1} \alpha_{i} \Delta X_{t-i}+\delta_{1} \Delta X_{t+1}+u_{t} .
$$

Equation (10) states that employment is affected by three components: the long-run relationship with explanatory variables through the parameter $\boldsymbol{\beta}=\left(\beta_{1}, \beta_{2}, \ldots\right)$, the short-run relationships with explanatory variables through the parameters $\alpha_{i}$ and $\delta_{1}$, and the lagged equilibrium correction mechanism, $\left(l_{t-1}-c-X_{t-1} \boldsymbol{\beta}\right)$, through the parameter $\gamma_{11}$. The equilibrium correction mechanism - that is, the correction for the deviation from the steady-state equilibrium - may be justified on two grounds. It represents not only an adjustment to the past due to technological and institutional rigidities but also an equilibrium error resulting from agents' expectations or forecasts of changes in employment. The latter stem from the possibility that agents may have more information about the employment variable they are trying to forecast than is contained in the history of the variable alone (see Campbell and Shiller 1988, 507).

Economizing on the number of degrees of freedom, differenced variables in lag or lead forms are progressively eliminated if they do not con- 
tribute to the overall fit. Cointegration results are reported on a countryby-country basis.

\subsubsection{Barbados}

The following variables in levels are of interest here: logarithm of number of employees $(L)$, logarithm of real wage index (WR), logarithm of real GDP (GDP), logarithm of contributions to NIS (NISCOR), and severance payments variable (SEV). Other details concerning these variables are provided in the appendix.

The Johansen trace and maximum eigenvalue tests in table 10.10 reveal the presence of one cointegrated vector among the set of variables just mentioned at the 5 percent level (and presumably at the 10 percent level). Indeed, the trace statistic value for no cointegration (85.31) is greater than the critical value (68.52) at the 5 percent level of significance while the statistic value for at most one cointegrated relationship (46.77) is less than the

Table 10.10 Johansen Cointegration Tests: Barbados

\begin{tabular}{|c|c|c|c|}
\hline & \multicolumn{3}{|c|}{$\begin{array}{l}\text { Period: } 1970-2001 \\
\text { Trend assumption: Linear deterministic trend } \\
\text { Series: } L, W_{r} \text {, GDP, NISCOR, SEV } \\
\text { Lags interval (in first differences): } 1 \text { to } 1 \\
\text { Unrestricted Cointegration Rank Test }\end{array}$} \\
\hline \multirow{2}{*}{$\begin{array}{l}\text { Hypothesized } \\
\text { No. of CE(s) }\end{array}$} & \multirow{2}{*}{$\begin{array}{c}\text { Trace } \\
\text { Statistic }\end{array}$} & \multicolumn{2}{|c|}{ Critical Value } \\
\hline & & 5 Percent & 1 Percent \\
\hline None** & 85.31158 & 68.52 & 76.07 \\
\hline At most 1 & 46.77154 & 47.21 & 54.46 \\
\hline At most 2 & 24.86835 & 29.68 & 35.65 \\
\hline At most 3 & 11.70971 & 15.41 & 20.04 \\
\hline \multirow[t]{3}{*}{ At most 4} & 1.576054 & 3.76 & 6.65 \\
\hline & & \multicolumn{2}{|c|}{ Critical Value } \\
\hline & Eigenvalue Statistic & 5 Percent & 1 Percent \\
\hline None* & 38.54003 & 33.46 & 38.77 \\
\hline At most 1 & 21.90319 & 27.07 & 32.24 \\
\hline At most 2 & 13.15864 & 20.97 & 25.52 \\
\hline At most 3 & 10.13366 & 14.07 & 18.63 \\
\hline At most 4 & 1.576054 & 3.76 & 6.65 \\
\hline
\end{tabular}

Notes: Variables are defined in table 10.9. Hypothesized no. of CE(s) stands for the number of cointegrating equation(s). Trace statistic and maximum eigenvalue statistic are the statistics of interest here for testing cointegration.

**Significant at the 5 percent level.

*Significant at the 10 percent level. 
Table 10.11 Long-Run Estimates from a Variant of Equation (10) using the Phillips-Loretan Nonlinear Least Squares: Barbados, 1970-2001

\begin{tabular}{lcccc}
\hline Constant & WR & GDP & NISCOR & SEV \\
\hline$-3.197 \quad-0.328$ & 1.104 & 0.077 & -0.018 \\
$(-1.828)$ & $(-2.662)$ & $(5.088)$ & $(1.220)$ & $(-0.877)$ \\
$R^{2}=0.986$ & & & \\
$R^{2}=0.974$ & & & \\
LM $(F$-statistic $)=0.718 \quad p=0.555$ & & \\
ARCH $(F$-statistic $)=0.227 \quad p=0.799$ & & \\
Jarque-Bera $=0.236 \quad p=0.889$ & & \\
Wald $(F$-statistic $)=1.362 \quad p=0.281$ & & \\
\hline
\end{tabular}

Notes: Variables are defined as in table 10.9. Short-run estimates are not reported here. Numbers in parentheses are $t$-statistics. LM test is the Breusch-Godfrey test for serial correlation using the $F$-test version because of the small sample size. ARCH test is the autoregressive conditional heteroskedasticity test. Jarque-Bera is the test for normality. $p$-value is the $p$-value associated with the respective test. Wald tests for the overall restriction that regulations do not matter, that is, impact NISCOR $=$ impact $\mathrm{SEV}=0$.

critical value (47.21). Similarly, for the maximum eigenvalue statistic, the value for no cointegration (38.54) is greater than the 5 percent critical value (33.46), while at the same time the value for at most one cointegration (21.90) is less than the 5 percent critical value (27.07).

A parsimonious form of equation (10) with the variables previously indicated is used to estimate the long-run parameters. For reasons of space and also because the focus is on the long-run parameters, the coefficients of the lags and the leads of differenced variables are not reported here. Table 10.11 contains the results of the preferred model. The latter passes the diagnostic tests of interest here. Indeed, at the 5 percent level of significance, there is no autocorrelation of errors as the LM test in its $F$ version with a $p$-value of 0.56 indicates. Autoregressive conditional heteroskedasticity $(\mathrm{ARCH})$ effects are also absent in this model, as the associated $p$ value (0.80) implies. The model also passes the test of normality as indicated by the $p$-value of the Jarque-Bera test. As far as impacts of variables are concerned, real wage and real GDP significantly affect labor demand. The constant term that captures omitted variables is also significant at the 5 percent level. A 1 percent increase in real wage depresses demand for labor by 0.33 percent, at least in the long run. A 1 percent increase in the real GDP brings about a 1.10 percent increase in employment. Severance payments have a negative but insignificant effect on employment. Contributions to national insurance do not affect employment. Results from the Wald test for restrictions indicate that regulations taken as a whole (contribution to NIS and severance payments) do not affect the path of employment in Barbados. 


\subsubsection{Jamaica}

The variables of interest are logarithm of number of employees $(l), \log$ arithm of the Kaitz index (KAITZ), logarithm of real GDP (GDP), logarithm of contributions to NIS (NISCOR) and severance payments variable (SEV).

The Johansen trace and maximum eigenvalue statistic tests in table 10.12 indicate the existence of two cointegrated vectors at the 5 percent level and one cointegrated vector at the 1 percent level. Given the nature of the exercise, the emphasis is on the existence of a single cointegrated vector.

Table 10.13 contains the estimation results of a variant of equation (10). The results indicate that there is no autocorrelation of errors as implied by the size of $p$-value ( 0.321$)$ of the LM test in its $F$ version. Moreover, there are no ARCH effects as the associated $p$-value (0.766) indicates. The model also passes the Jarque-Bera test of normality. As for Barbados, in Jamaica real GDP has a significant impact on employment, at least in the long run. A 1 percent increase in real GDP brings about a 0.39 percent increase in employment levels. The impact of minimum wage through the Kaitz index

Table 10.12 Johansen Cointegration Test: Jamaica

Period: 1975-2001

Trend assumption: Linear deterministic trend

Series: $L$, KAITZ, GDP, NISCOR, SEV

Lags interval (in first differences): 1 to 1

Unrestricted Cointegration Rank Test

\begin{tabular}{lccr}
\hline & & \multicolumn{2}{c}{ Critical Value } \\
\cline { 3 - 4 } Hypothesized & Trace & 5 Percent & 1 Percent \\
\hline No. of CE(s) & Statistic & 68.52 & 76.07 \\
None** & 100.3251 & 47.21 & 54.46 \\
At most 1* & 53.81603 & 29.68 & 35.65 \\
At most 3 & 27.47777 & 15.41 & 20.04 \\
At most 4 & 11.95671 & 3.76 & 6.65 \\
& 2.539234 & \multicolumn{2}{c}{ Critical Value } \\
\cline { 2 - 4 } & & 5 Percent & 1 Percent \\
& Maximum & 33.46 & 38.77 \\
None** & 46.50906 & 27.07 & 32.24 \\
At most 1 & 26.33827 & 20.97 & 25.52 \\
At most 2 & 15.52105 & 14.07 & 18.63 \\
At most 3 & 9.417478 & 3.76 & 6.65 \\
At most 4 & 2.539234 & \multicolumn{2}{c}{} \\
\cline { 2 - 4 } & & &
\end{tabular}

Notes: See table 10.10.

**Significant at the 5 percent level.

*Significant at the 10 percent level. 
Table 10.13

Long-Run Estimates from a Variant of Equation (10) using the Phillips-Loretan Nonlinear Least Squares: Jamaica, 1975-2001

\begin{tabular}{lcccc}
\hline Constant & KAITZ & GDP & NISCOR & SEV \\
\hline $3.515 \quad(-2.112)$ & $(2.013)$ & 0.023 & 0.048 \\
$(2.505)$ & & & $(1.803)$ \\
$R^{2}=0.985$ & & & \\
$R^{2}=0.965$ & & & \\
$\mathrm{LM}(F$-statistic $)=1.381 \quad p=0.321$ & & \\
ARCH $(F$-statistic $)=0.271 \quad p=0.766$ & & \\
Jarque-Bera $=0.631 \quad p=0.730$ & & \\
Wald $(F$-statistic $)=2.727 \quad p=0.114$ & & \\
\hline
\end{tabular}

Notes: See table 10.11.

is worth noting. Indeed, a 1 percent increase in the Kaitz index depresses employment by about 0.18 percent. Contributions to NIS do not seem to have an impact on employment. Severance payments do not affect employment at the 5 percent level. Overall, regulations taken as a whole do not have a significant impact on employment, as the Wald test on restrictions suggests with a $p$-value of 0.114 .

\subsubsection{Trinidad and Tobago}

The variables of interest are logarithm of number of employees $(l), \log$ arithm of effective minimum wage index (EMV), logarithm of real GDP (GDP), contributions to NIS in dummy variable (NISCOR), and severance schemes captured by a dummy variable (SEV). NISCOR and SEV are quantified as explained in the appendix.

The Johansen trace and maximum eigenvalue test values in table 10.14 indicate the presence of one cointegrated vector at the 1 percent and 5 percent and consequently 10 percent levels of significance.

Table 10.15 contains the estimation results of a variant of equation (10). The results indicate that there is no autocorrelation of errors as implied by the size of $p$-value ( 0.75$)$ of the LM test in its $F$ version. There are no ARCH effects, as the associated $p$-value (0.38) indicates. The model also passes the Jarque-Bera test of normality. As for Barbados and Jamaica, real GDP has a significant impact on labor demand, at least in the long run. A 1 percent increase in real GDP brings about a 0.22 percent increase in employment levels. Regulation variables, although having the right signs, are nevertheless not significant at the 5 percent level. The Wald test for the overall impact of regulations indicates that regulations do not affect employment levels in Trinidad and Tobago.

The empirical analysis of the impact of labor regulations on employment in Barbados and Jamaica as well as in Trinidad and Tobago indicates that changes in contributions to NIS (payroll taxes) and severance pay- 
Table 10.14 Johansen Cointegration Test: Trinidad and Tobago

\begin{tabular}{|c|c|c|c|}
\hline \multicolumn{4}{|c|}{$\begin{array}{l}\text { Period: } 1970-1999 \\
\text { Included observations: } 28 \text { after adjusting endpoints } \\
\text { Trend assumption: No deterministic trend (restricted constant) } \\
\text { Series: } L \text {, EMV, GDP, NISCOR, SEV } \\
\text { Lags interval (in first differences): } 1 \text { to } 1 \\
\text { Unrestricted Cointegration Rank Test }\end{array}$} \\
\hline \multirow{2}{*}{$\begin{array}{l}\text { Hypothesized } \\
\text { No. of } C E(s)\end{array}$} & \multirow{2}{*}{$\begin{array}{c}\text { Trace } \\
\text { Statistic }\end{array}$} & \multicolumn{2}{|c|}{ Critical Value } \\
\hline & & 5 Percent & 1 Percent \\
\hline None** & 101.4524 & 76.07 & 84.45 \\
\hline At most 1 & 47.59449 & 53.12 & 60.16 \\
\hline At most 2 & 29.97064 & 34.91 & 41.07 \\
\hline At most 3 & 15.28983 & 19.96 & 24.60 \\
\hline \multirow[t]{3}{*}{ At most 4} & 6.240594 & 9.24 & 12.97 \\
\hline & Moxim & \multicolumn{2}{|c|}{ Critical Value } \\
\hline & Eigenvalue Statistic & 5 Percent & 1 Percent \\
\hline None ${ }^{* *}$ & 53.85791 & 34.40 & 39.79 \\
\hline At most 1 & 17.62385 & 28.14 & 33.24 \\
\hline At most 2 & 14.68081 & 22.00 & 26.81 \\
\hline At most 3 & 9.049235 & 15.67 & 20.20 \\
\hline At most 4 & 6.240594 & 9.24 & 12.97 \\
\hline
\end{tabular}

Notes: See table 10.10.

**Significant at the 5 percent level.

ments do not have an impact on the level of employment. With the exception of Jamaica, minimum wage does not affect the level of employment either. To a large degree, these different results are by and large explained by a lack of significant change in LMR over the period of the study. The key factor driving employment in the three countries is output growth.

Despite the reservations put forward at the beginning of this section (shortness of samples-for Jamaica, in particular-reliance on large sample tests, and poor-quality data), there are two reasons that point to some reliability of results. First, the econometric results in this study corroborate, to a large extent, the results of a survey of employers in five Caribbean countries (see Abt Associates 1998). The study indicates that "most companies reported that legislation was not an important labour market issue affecting their company" (26). The low values on the various indexes of labor market rigidity, employment protection, or labor market distortion also suggest that LMR is not a major factor in employment determination in the region. The key to employment generation lies in output growth. Second, the results derived from annual data are by and large concordant with those with quarterly data (not reported here) generated from 
Table 10.15

Long-Run Estimates from a Variant of Equation (10) using the PhillipsLoretan Nonlinear Least Squares: Trinidad and Tobago, 1970-1999

\begin{tabular}{lcccc}
\hline Constant & EMV & GDP & NISCOR & SEV \\
\hline 3.576 & -0.009 & 0.222 & -0.025 & -0.028 \\
$(3.273)$ & $(-0.125)$ & $(1.932)$ & $(-1.344)$ & $(-1.058)$ \\
$R^{2}=0.955$ & & & \\
$R^{2}=0.938$ & & & \\
LM $(F$-statistic) $=0.400 \quad p=0.753$ & & & \\
ARCH $=1.018 \quad p=0.378$ & & \\
Jarque-Bera $=0.568 \quad p=0.753$ & & \\
Wald $(F$-statistic $)=0.963 \quad p=0.431$ & & \\
\hline
\end{tabular}

Notes: See table 10.11.

annual data. Yet with large sample sizes, quarterly data results do not suffer from the problem of "reliance on asymptotic tests."

\subsection{Conclusion}

Employment creation has been a major economic challenge in the Caribbean. The existence of a range of regulatory measures has been identified by some commentators as a source of labor market rigidity in the region. This research study has examined the range of direct and indirect LMRs in the region. Although several regulations exist in the countries under study, the overall level of labor market distortion caused by these regulations has been small compared with Latin American countries. Furthermore, the adoption of the voluntaristic model of industrial relations by a number of countries has meant that there has been little change in the labor laws in the region over time. For example, the severance payment acts in Trinidad and Tobago and Jamaica have not changed significantly since their introduction. The econometric analysis of the impact of selected regulations (that is, the minimum wage, contributions to the NIS, and severance payments) on employment indicates that these measures have had little statistical significance. Output growth has been identified as a key factor in generating employment in the region.

This study was limited by the small sample size, in particular for Jamaica. One solution might have been to pool data. However, pooling the data from the three countries is not advisable here for at least two reasons. First, there is a lack of homogeneity in the measurements or definitions of variables in some instances: For example, wage is defined as average earnings in Trinidad and Tobago, average compensation in Jamaica, and average wage rate in Barbados; contributions to the NIS are unweighted index of rates in Barbados, unweighted simple index of the maximum wage related payment in Jamaica, and a dummy variable in Trinidad and Tobago. 
Consequently, interpreting the results from a pooled model becomes very hazardous. Second, a good or relevant panel data implies that the country dimension is much larger than the time dimension. This is not the case with our data. Another solution is to generate quarterly data from annual data to enlarge the sample size. The problem is that while data aggregation rests on a sound theoretical framework, data disaggregation when only aggregated data exist, in contrast, reposes generally on a dubious theoretical ground. Hence, given the nonexistence of quarterly data and the pooling problems noted here, the way out is to enlarge the data span by collecting more annual data to obtain reliable estimates.

\section{Appendix}

\section{Statistical Measurement of Labor Market Regulations}

\section{Barbados}

Severance payments $\quad 1970-1977 \quad 0 \quad$ (scheme introduced in 1973) (dummy variable) $\quad 1978-1990 \quad 1 \quad$ (scheme changed in 1978)

1991-2001 2 (change in scheme in 1991)

National insurance payments: simple unweighted index of the rates of contribution by employees and employers (1970-2001)

Jamaica

Severance payments $\quad 1975-1985 \quad 1 \quad$ (scheme introduced in 1974) (dummy variable) $\quad 1986-1987 \quad 2 \quad$ (change in scheme in 1986)

1988-2001 3 (change in scheme in 1988)

National insurance payments: simple unweighted index of the maximum wage-related payments (1975-2001)

National minimum wage: simple unweighted index of the minimum wage (started in 1975-2001)

Kaitz index: ratio of the national minimum index to the average compensation index (1975-1996)

Trinidad and Tobago

$\begin{array}{clll}\text { Severance payments } & 1970-1985 & 0 & \text { (no scheme) } \\ & 1986-1999 & 1 & \text { (introduced in 1971) } \\ \text { National insurance } & 1970 & 0 & \text { (no scheme) } \\ \text { payments } & 1971-1979 & 1 & \text { (introduced in 1971) } \\ & 1980-1982 & 2 & \text { (changed in 1980) } \\ & 1983-1998 & 3 & \text { (changed in 1983) } \\ & 1999- & & \text { (changed in 1999) }\end{array}$


Minimum wage index: simple unweighted index of selected minimum wage rates (1970-1999)

Sources: of minimum wage data is Central Bank of Trinidad and Tobago, various years and Central Statistical Office, various years-a,b.

\section{Statistical Measurement of Wages/Earnings}

\section{Barbados}

The Wage Rate Index (1970-2001) is a Laspeyres index and is the arithmetic mean of wages and salaries indices for hourly-paid skilled laborers in selected sectors using a forty-hour week as the basis of calculation. Weights are based on the percentage of total employment provided by each sector.

Sources: Central Bank of Barbados, various years; International Monetary Fund, various years; Ministry of Finance and Planning, various years. Jamaica

In the Average Compensation Index (1975-2001), the ratio of total employees' compensation in the national accounts to total number of persons employed is used as a measure of average annual compensation. The dollar values are converted to simple unweighted index number form using 1985 as the base year.

Sources: International Monetary Fund, various years-b; National Insurance Scheme, various years; Planning Institute of Jamaica, various years; Statistical Institute of Jamaica, various years.

Trinidad and Tobago

The Average Weekly Earnings Index (1976-1999) covers average weekly earnings of employees in the manufacturing, oil, sugar, and electricity sectors.

Sources: Central Bank of Trinidad and Tobago, various years; Central Statistical Office, various years-a,b.

Note: In all cases the real values were obtained by deflating by the retail price index.

\section{Statistical Measurement of GDP and Employment}

Data on GDP at constant prices were obtained from the national accounts of the three countries, while employment data were obtained from labor force surveys. In the case of Barbados, estimates of employment for the period 1970-1974 were obtained from Downes and McClean (1988). 


\section{References}

Abt Associates. 1998. Workers and labour markets in the Caribbean. IADB Background Document, vol. 2. Washington, D.C.: Inter-American Development Bank, May.

Antoine, R. 1992. The CARICOM labour law harmonization report. Cave Hill, Barbados: University of the West Indies, Faculty of Law. 1998. The economic implications of labour law in the IDB CARICOM countries. University of the West Indies. Working Paper.

Baker, J. L. 1997. Poverty reduction and human development in the Caribbean: A cross-country study. World Bank Discussion Paper no. 366. Washington, D.C.: World Bank.

Brown, C., C. Gilroy, and A. Kohen. 1982. The effect of minimum wage on employment and unemployment. Journal of Economic Literature 20 (2): 487-528.

Campbell, J. Y., and R. J. Shiller. 1988. Interpreting cointegrated models. Journal of Economic Dynamics and Control 12 (2/3): 505-22.

Central Bank of Barbados. Various years. Annual statistical digest. Bridgetown, Barbados: Central Bank of Barbados.

Central Bank of Trinidad and Tobago. Various years. Handbook of key economic statistics. Port of Spain, Trinidad and Tobago: Central Bank of Trinidad and Tobago.

Central Statistical Office. Various years-a. Annual statistical digest. Port of Spain, Trinidad and Tobago: Central Statistical Office.

- Various years-b. Labour digest. Port of Spain, Trinidad and Tobago: Central Statistical Office.

Cumberbatch, J. 1995a. Wrongful dismissal and the "retreat" from Barbados Plastics. Anglo-American Law Review 24:213-35.

. 1995b. Plastic surgery - wrongful dismissal in Barbados after Grosvenor v. the Advocate Co. Ltd.: A comment. Caribbean Law Review 5 (1): 314-35.

Downes, A. S. 2002. Indices of labour market regulation: Principles and cases. Indian Journal of Labour Economics 45 (1): 117-26.

Downes, A. S., and N. Mamingi. 1997. Dynamic labour demand functions with non-wage labour costs: Theory and estimation techniques. Institute of Social and Economic Research Working Paper no. 5. Cave Hill, Barbados: Institute of Social and Economic Research.

Downes, A. S., and W. McClean. 1998. The estimation of missing values of employment in Barbados. Research Papers (Central Statistical Office, Trinidad and Tobago) 13:115-36.

Erickson, C. L., and D. J. B. Mitchell. 1995. Labour market regulation, flexibility and employment. Labour 9 (3): 443-62.

Hamermesh, D. S. 1993. Labour demand. Princeton, N.J.: Princeton University Press.

Hamermesh, D. S., and G. A. Pfann. 1996. Adjustment costs in factor demand. Journal of Economic Literature 34 (3): 1264-92.

Inter-American Development Bank (IADB). 1996. Economic and social progress in Latin America report. Washington, D.C.: Inter-American Development Bank.

International Monetary Fund. Various years-a. Barbados: Recent economic developments. Washington, D.C.: International Monetary Fund.

. Various years-b. International financial statistics handbook. Washington, D.C.: International Monetary Fund.

Intriligator, M. D. 1971. Mathematical optimization and economic theory. Englewood Cliffs, N.J.: Prentice Hall. 
La Foucade, A. 1995. A review of the evaluation and performance of social security schemes in the English-speaking Caribbean. Port of Spain, Trinidad and Tobago: Inter-American Conference on Social Security/National Insurance Board of Trinidad and Tobago.

Lazear, E. P. 1990. Job security provisions and employment. Quarterly Journal of Economics 105 (3): 699-726.

Loayza, N., and L. Palacios. 1997. Economic reform and progress in Latin America and the Caribbean. World Bank Working Paper no. 1829. Washington, D.C.: World Bank.

Lockwood, B., and A. Manning. 1989. Dynamic wage-employment bargaining with employment adjustment costs. Economic Journal 99 (398): 1143-58.

Maddala, G. S., and I. M. Kim. 1998. Unit roots, cointegration and structural change. Cambridge, U.K.: Cambridge University Press.

Márquez, G., and C. Pagés. 1998. Ties that bind: Employment protection and labour market outcomes in Latin America. Inter-American Development Bank. Mimeograph.

Ministry of Finance and Planning. Various years. Barbados economic report. Bridgetown, Barbados: Government of Barbados.

Modesto, L. 1994. Dynamic behaviour of wages and employment: A bargaining model introducing adjustment costs. CEPR Discussion Paper no. 893. London: Centre for Economic Policy Research.

National Insurance Scheme. Various years. Annual report. Kingston, Jamaica: National Insurance Scheme.

Phillips, P. C. B., and M. Loretan. 1991. Estimating long run economic equilibria. Review of Economic Studies 58 (195): 407-36.

Planning Institute of Jamaica. Various years. Economic and social survey of Jamaica. Kingston, Jamaica: Planning Institute of Jamaica.

Rama, M. 1995. Do labour market policies and institutions matter? The adjustment experience in Latin America and the Caribbean. Labour 9:S243-S268.

Sapsford, D., and Z. Tzannatos. 1993. The economics of the labour market. London: MacMillan.

Statistical Institute of Jamaica. Various years. Labour market information newsletter of Jamaica. Kingston, Jamaica: Statistical Institute of Jamaica.

World Bank. 1995. World development report. Washington, D.C.: World Bank.

Zank, N. S. 1996. Measuring the employment effects of regulation: Where did the jobs go? London: Quorum Books. 
